\title{
Supplying water to a water-stressed city: lessons from Windhoek
}

\author{
Michel LAFFORGUE
}

Suez Consulting - Le Bruyère 2000 Bâtiment 1 - zone du millénaire - 650 rue Henri Becquerel - CS79542 - 34961 Montpellier Cedex 2, France, michel.lafforgue@suez.com

\begin{abstract}
Windhoek, the capital of Namibia, is located in a semi-desert region, a long way from the sea and from its main surface water and groundwater sources. The city's population (a significant proportion of which lives in informal settlements) is growing. It has however been successful in meeting the water needs of its citizens, and has done so by working on several different fronts. Admittedly, part of the city's water supply is brought in from dams located some distance away from the city and, as is fairly conventional, these supplies supplement local groundwater sources. These resources are insufficient however, a problem that the City of Windhoek (CoW) has strived to address by reducing water demand on the one hand and increasing supply sources on the other. One of the major innovations is the use of dual wastewater reuse loops. In the first place the city has a reticulation system providing treated wastewater for the needs of parks and gardens. After been blended with treated surface water and sent to the city's drinking water system, a large part of this treated wastewater is used to provide drinking water however. The surplus water from rainy years is then injected into the underlying aquifer to ensure a backup supply source for dry years. In this way, as much as one quarter of the city's water needs is provided through wastewater reuse loops. Other valuable insights are to be gained from the analysis of social and cultural contingencies and their impact on the viability of water supply projects.

These achievements are a possible source of inspiration for Mediterranean cities, many of which have certain points in common with Windhoek. There are also lessons to be learned for the rest of Europe. This paper looks at the applicability of the Windhoek case to the Mediterranean context in the light of the specific characteristics of southern Europe and northern Africa.
\end{abstract}

Key-words: drinking water supply, Windhoek, wastewater reuse, water stress, urban water cycle

\section{Comment alimenter une ville en stress hydrique : les enseignements tirés de Windhoek}

\begin{abstract}
RÉSUMÉ. - Windhoek, capitale de la Namibie, est localisée en environnement semi désertique, loin de la mer et des principales ressources en eaux superficielles ou souterraines. Sa population est croissante (avec une proportion significative en habitat bas standing). Elle arrive cependant à approvisionner cette population, en jouant sur plusieurs leviers. Certes, la ville utilise des transferts d'eau à moyenne distance à partir de 3 barrages, en complément des eaux souterraines locales, ce qui est classique. Ces ressources sont cependant insuffisantes, et COW (City of Windhoek) a agi pour d'une part réduire la demande en eau, et d'autre part augmenter les ressources disponibles. L'une des innovations majeures vient de l'intégration de 2 boucles de réutilisation des eaux usées. La ville dispose tout d'abord d'un réseau dédié à l'arrosage des espaces verts à partir d'eau usée traitée. Mais surtout elle potabilise une partie notable de ses eaux usées, cette eau étant mélangée avec des eaux de surface traitées puis envoyée dans le réseau d'eau potable de la ville. Le surplus des années humides est alors injecté dans l'aquifère situé sous une partie de la ville, ce qui permet d'assurer une réserve pour les années sèches. Ainsi, le 1/4 des besoins de la ville provient d'ores et déjà des boucles de réutilisation. Un autre des enseignements important vient de l'analyse des contingences socio-culturelles et de leur impact sur la viabilité des projets de desserte en eau des populations.

Cette expérience peut être source d'inspiration pour de nombreuses villes du pourtour méditerranéen qui présentent certaines similitudes contextuelles avec Windhoek, mais elle peut être également utile dans le reste de l'Europe. Ainsi, l'applicabilité de l'expérience de Windhoek dans un contexte Méditerranéen est analysée à l'aulne des spécificités de l'Europe du Sud et du nord de l'Afrique.
\end{abstract}

Mots-clés : Alimentation en eau potable, Windhoek, Réutilisation des eaux usées, stress hydrique, cycle urbain de l'eau

\section{INTRODUCTION}

Most Mediterranean cities are experiencing rapid population growth $-\mathrm{a}$ trend that is set to intensify between now and 2050. And as urban populations expand, there will be a concomitant growth in water demand as more water is required to meet their drinking water needs. Indeed, at the global level, water demand forecasts put this growth at 50\% between 2010 and 2030 (2030 Water Resource Group, 2009). Further, the expected rise in summer temperatures over the same period, will inevitably drive up demand for water for irrigation and power generation purposes. And as a trend occurring right alongside the rise in water demand, global warming will have the effect of reducing the availability of water resources in the Mediterranean regions, exacerbating water stress in those of the major North African cities that are already experiencing water supply cuts. The options commonly used to address these problems have included increasing water storage capacities (as has been the case in the Moroccan city of Rabat), building water transfer schemes 
(such as the South-North Water Transfer Scheme in Algeria and the Great Man-Made River Project in Libya) and developing desalination capacity (as in Oran and Barcelona).

The drawbacks associated with these solutions are significant however:

- Installing extra capacity by impounding water in dams can result in land and villages being flooded. But the major adverse affects of this solution are two-fold, the first being a build-up of sediment in the reservoirs impounded. This is a phenomenon that has occurred at varying rates in the reservoirs of the Maghreb, thereby reducing their water storage capacity. And in the case of the Aswan Dam, the result has been an increase in the salinity of, and headward erosion into, the fertile land of the Nile Delta. The second major adverse effect is the loss of water through evaporation - the severity of which is amplified in the Mediterranean regions by the hot, dry summers experienced in that part of the world.

- While many water transfer systems involve the transfer of water between reservoirs, there are also several cases of transfers between wellfields and centres of consumption. The prime example of the latter is Libya's Great Man Made River, where water is transported over distances as great as $800 \mathrm{~km}$. But groundwater sources in the region are rarely perennial, and so do not constitute a viable supply source for the long term. Such transfer systems are moreover costly to build and have significant energy requirements - a potential drawback given the general upward long term trend in energy prices.

- As for desalination, this is only feasible for cities in coastal locations. And despite the fact that reverse osmosis is a scalable process and the cost of implementing is decreasing, the high energy requirements of desalination are another drawback to this technology.

But there are also various other possibilities which, despite offering considerable potential have been little explored to date as an option for Mediterranean regions. The example of Windhoek in Namibia (a city that has experienced water stress for decades now) has many lessons to offer, which could be put to good use to improve water management in Mediterranean countries. The characteristics of such water management strategies have been analysed in the Syracuse research project, which looks among others at the synergies to be derived between water, energy and waste cycles and at the use of small-loop cycles (Lafforgue et al., 2013). This article looks at the specific characteristics of water management in Windhoek and to what extent these can be transposed to the Mediterranean context.

\section{WINDHOEK}

\section{II.1. The context}

Windhoek is the capital of Namibia, a country which borders with South Africa. The city lies at an altitude of $1,500 \mathrm{~m}$, has a population of around 300,000 (2012 level, as compared to 100,000 in the 1980 s) and, with 2000 people per square kilometre, a medium population density. From a social perspective, the city still bears the legacy of apartheid, with suburbs classified by housing typology. The informal settlements - housing some 100,000 people - tend to be concentrated in the northern and western parts of the city, while the high-income neighbourhoods are located in the south and east. Although water demand is continually rising (up from $6 \mathrm{Mm}^{3} /$ year in 1968 to $27 \mathrm{Mm}^{3} /$ year in 2012), there are very few local resources to cope with this trend. Indeed, groundwater sources contribute only $1.7 \mathrm{Mm}^{3} /$ year to the water supply, annual rainfall is low $(360 \mathrm{~mm})$, evaporation levels are high (up to $50 \%$ of the lakes storage capacity) and the city has no perennial rivers. In the sixties, the city embarked on a programme to expand its supply sources by means of three mechanisms: the storage of surface water in dams, wastewater reuse, and the optimisation of the aquifer located beneath the city.

\section{II.2. Water resources and treatment}

Surface water sources consist of three dams: Omatako, Swakopport and Von Bach, located at distances of $60 \mathrm{~km}$ to $185 \mathrm{~km}$ from the edge of the city. Annually, these resources provide roughly $17 \mathrm{Mm}^{3}$ of water for Windhoek and $3 \mathrm{Mm}^{3}$ for the communities located on the way to Windhoek (Van der Merwe, 1999, Van der Merwe 2009). The main problem with this resource is that it is strongly dependent on meteorological conditions and on rainfall in particular (it explains the great temporal variability of the water production from surface and underground resources as presented in Figure 2). Another problem is that roughly $50 \%$ of the water (roughly $3.5 \mathrm{~m}$ per year) is lost through evaporation.

By the end of the sixties, when it became clear that the city's needs could no longer be met by conventional supply sources, the City of Windhoek (CoW) embarked on a programme of wastewater reuse. This was to make it the first capital city in the world to recycle wastewater for drinking water purposes. The recycling system adopted employs treatment processes that are compatible with the different uses. Domestic effluent is treated in activated sludge and biofilter systems, before being sent to:

- The old Goreangab water reclamation plant (“old GWRP”) built in 1968 with a capacity of 3,300 $\mathrm{m}^{3} /$ day and expanded to a capacity of $7,500 \mathrm{~m}^{3} /$ day in 1997 . The plant was initially used for drinking water purposes, but now produces semi-purified water for the needs of the city's parks and gardens (at $1.3 \mathrm{Mm}^{3} /$ year, the plant's current output accounts for only $8 \%$ of total water needs (Van der Merwe, 2013)).

- The new Goreangab water reclamation plant (NWGRP) a $21,000 \mathrm{~m}^{3} /$ day facility built in 2002 (Lahnsteiner et al., 2013) and incorporating the treatment process shown in Figure 1 (this treatment includes a multi-barrier system, more especially composed of several filtration processes. However, if the ultrafiltration step is sufficient for pathogens removal, it is not sufficient for managing dissolved salts). The reclaimed water is blended with conventionally treated surface water in a ratio of one third to two thirds (Van der Merwe et al., 2006) and, in 2003, accounted for $26 \%$ of the total amount of water produced (Van der Merwe, 2009). Blending is used for two main reasons. In addition to the safety implications, it is also used to dilute the treated wastewater with low-salinity water.

As shown on Figure 2, the consumption increase from 1990 to 2010 was mainly sustained by the increase of reused water, and without that new resource, the city would had to face a strong deficit of water production.

But as the population continued to grow, by the end of the 1990s the CoW had begun looking at possibilities for supplementing existing supply sources. This included pumping from the Tsumeb aquifer (located $490 \mathrm{~km}$ from the city), pumping from the Okavango river $(750 \mathrm{~km}$ from the city), include a Managed Aquifer Recharge (MAR) in the southern part of Windhoek, and additional treatment to increase the proportion of reclaimed water in the treated water mix. Table 1 illustrates these different options with the indication 


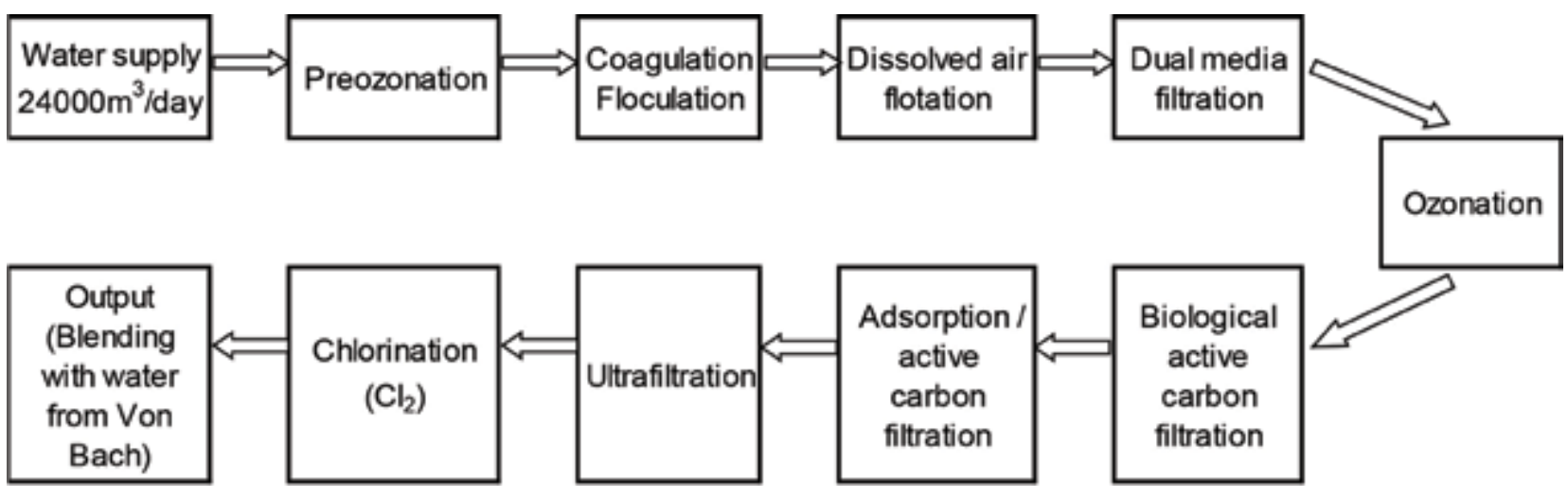

Figure 1: Processes at the New Goreangab water reclamation plant (Lafforgue et al., 2015b).

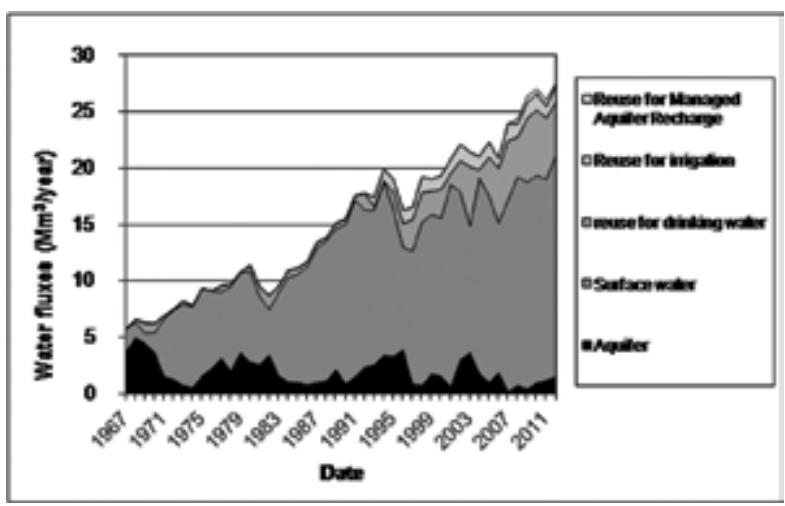

Figure 2: Evolution of water production in Windhoek as a function of supply source (Lafforgue et al., 2015b).

of the distance of the water from Windhoek, the energy required per $\mathrm{m}^{3}$ to transfer and treat the water and the corresponding cost per $\mathrm{m}^{3}$. MAR clearly emerges as the optimal solution, providing storage for up to $33 \mathrm{Mm}^{3}$ of water and even $60 \mathrm{Mm}^{3}$ including deep aquifers (Van der Merwe et al., 2013; Murray et al., 2013; Peters, 2013).

It was then decided to optimise the use of the aquifer underlying the city. This aquifer contributed between $0 \mathrm{Mm}^{3}$ and $5 \mathrm{Mm}^{3}$ of water per year (with a mean output of $1.7 \mathrm{Mm}^{3} /$ year). In order to realise the full potential of the aquifer, it was decided to inject the surplus water left over in rainy years and to pump this out during dry years. This process will prevent the $50 \%$ water losses that occur due to evaporation (there is no evaporation from the aquifer) while providing additional storage capacity. The MAR process includes an additional Granular Activated Carbon (GAC) filtration and disinfection treatment to prevent bacterial growth and clogging of injection wells (Van der Merwe et al., 2013). To prevent contamination of groundwater, the injection wells are (and will continue to be) located in the southern part of the city, where human activities are regulated (Figure 3). The objective is to attain an injection capacity of $11 \mathrm{Mm}^{3} /$ year and a storage capacity of up to $60 \mathrm{Mm}^{3}$.

Figure 4 clarifies the different water quality (red colour for wastewater, yellow for partially treated effluent, green for improved quality and blue for drinking water quality), and associated uses. Moreover, one of the specificity of Windhoek urban water cycle is the organisation of water loops that differs from the classical urban water cycle (which is an opened cycle).

Windhoek also has a dual reticulation system, comprising one network for irrigation and watering of parks and gardens and supplying non-potable water to the city's cement plant. This system is supplied by treated wastewater from Old Goreangab, the older of the city's two water reclamation plants.

\section{II.3. Demand management}

As it was not possible to balance supply and demand simply by increasing the volume of water resources available, the CoW chose to implement measures to reduce water demand. The different measures adopted are as follows:

- Reducing water losses within the distribution system. This is achieved through a good knowledge of the water

Table 1: Comparison of options for increasing the supply of water for Windhoek (Van der Merwe, 2013, Lahnsteiner et al, 2013)

\begin{tabular}{|l|c|c|c|}
\hline Options & $\begin{array}{c}\text { Distance } \\
(\mathbf{k m})\end{array}$ & $\begin{array}{c}\text { Energy consumption } \\
\left(\mathbf{K w h} / \mathbf{m}^{\mathbf{3}}\right)\end{array}$ & $\begin{array}{c}\text { Treatment cost } \\
\left(\mathbf{e u r o s} / \mathbf{m}^{\mathbf{3}}\right)\end{array}$ \\
\hline Current supply sources & 0 to 200 & 0.8 to 1.5 & 0.35 to 0.95 \\
\hline Okavango river & 750 & 4.94 & 3.33 \\
\hline Tsumeb aquifer & 490 & ND & 2.22 \\
\hline Reclaimed water with additional water treatment process & 0 & 1.8 & 1.26 \\
\hline Managed Aquifer Recharge at Windhoek & 0 & 1.78 & 1.2 \\
\hline
\end{tabular}

$N B$ : Energy consumption is given for water treatment and conveyance up to the entrance of the water distribution system 


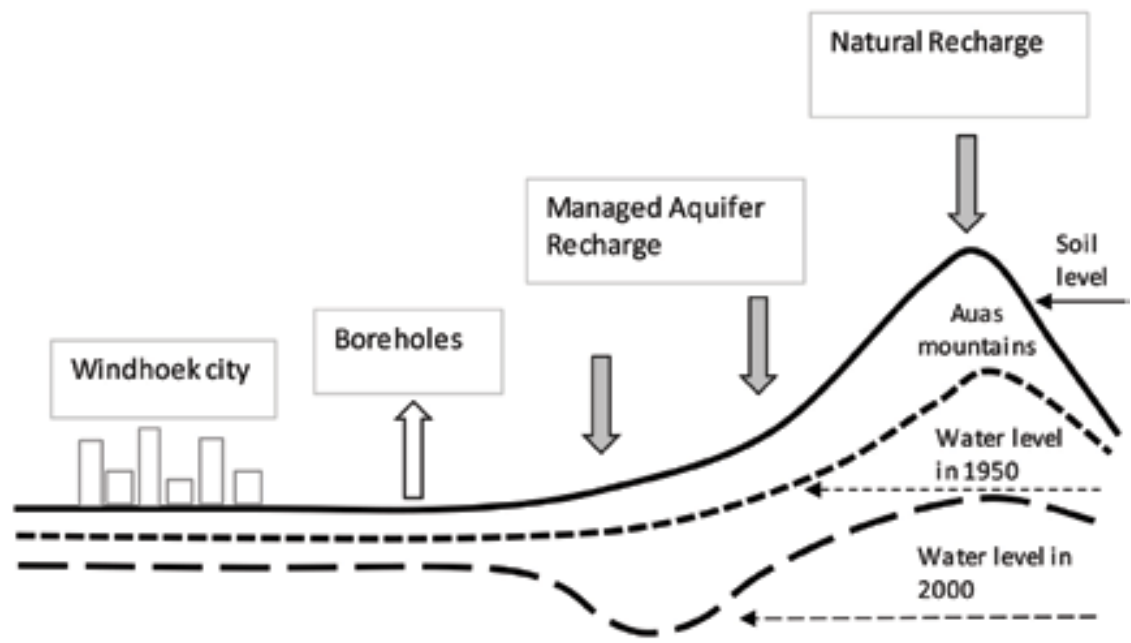

Figure 3: Scheme of the managed aquifer recharge in Windhoek (adapted from Mathews, 2003).

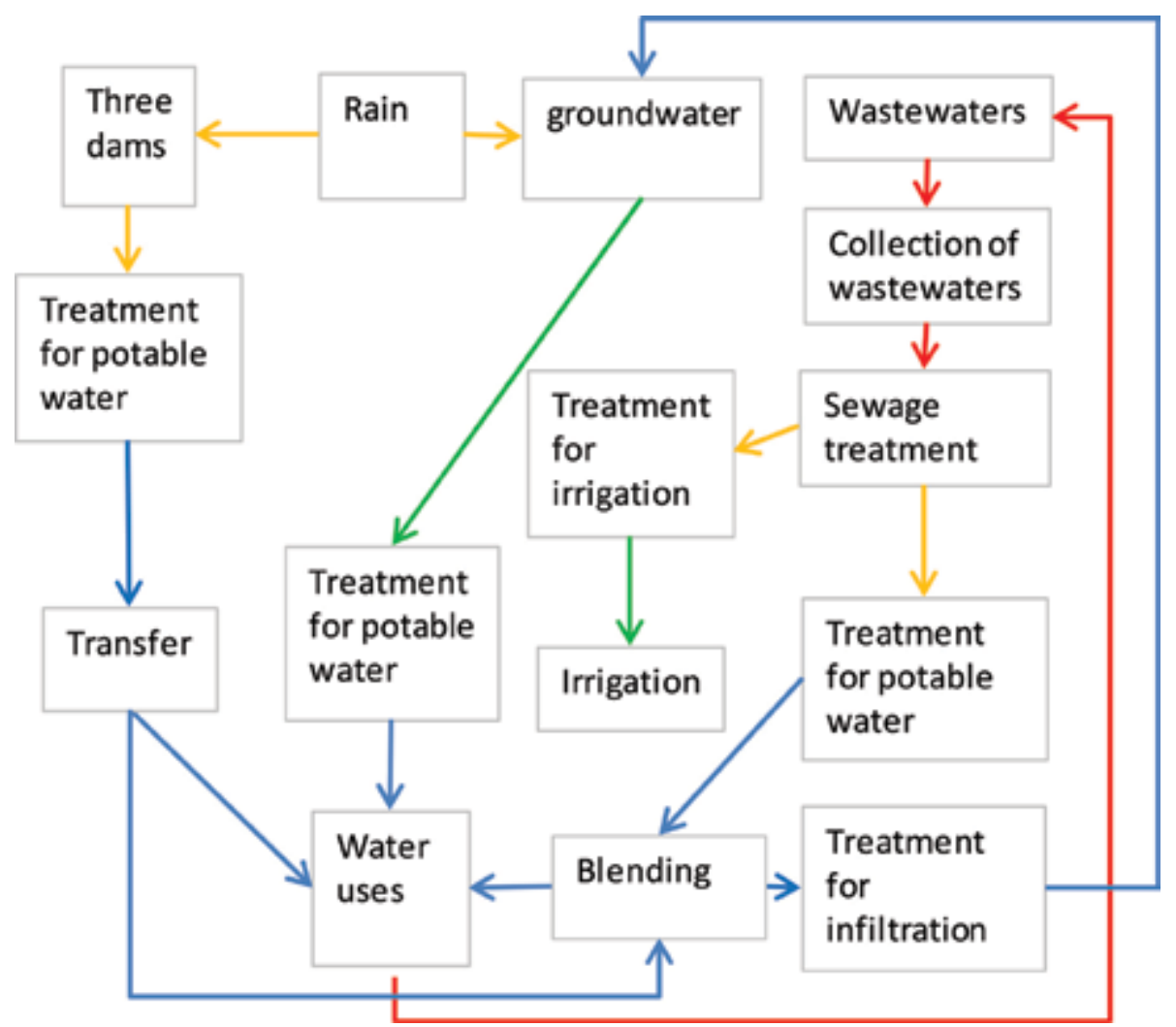

Figure 4: Urban water cycles in Windhoek (Lafforgue et al., 2015b).

infrastructure and targeted and efficient leak detection. In Windhoek, distribution system efficiency is in the $89 \%$ to $90 \%$ region - an impressive level, not only in comparison with those found in other African cities but also with typical levels in the Mediterranean cities of Europe. The city is now seeking to increase efficiency gains by a further $3 \%$ to $4 \%$ by targeting leakage in the informal settlements, where losses are thought to be highest.

- Communication campaigns. Radio, TV and local media have been used to educate the public about issues like saving water and the choices available in terms of plant species with low water requirements. Such campaigns have been used more specifically in periods of drought.

- A progressive and incentive-based tariff system. This comprises three blocks of tariffs, the first block (the so-called "social" tariff) being subsidised to ensure that the poor have the minimum amount of water required to meet their needs. The second block is an intermediate one that ensures full cost recovery. The third block is taxed with two aims in view: first to cover the cost of the social tariff and second and more importantly, to act as a disincentive to luxury consumption and wastage. Of particular interest 
from a regulatory standpoint: the values of the thresholds for switching between tariff blocks can be adjusted by the CoW by simple municipal order. These values can then be adjusted in accordance with the prevailing degree of water stress. The result is that, with the prospect of a water shortage looming, the municipality can act quickly to lower the values of the thresholds for switching between tariff blocks, with the effect of making water more expensive and rapidly driving down the consumption of water (dotted line on Figure 5). For instance, from 2010 to 2014 these thresholds were stable, the first block corresponding to $6 \mathrm{~m}^{3} / \mathrm{month} /$ connection the second from 6 to $45 \mathrm{~m}^{3} / \mathrm{month} /$ connection and the third above $45 \mathrm{~m}^{3} / \mathrm{month} /$ connection. Figure 5 illustrates the variable part of the water tariff for this period.

- Restrictions on water usage in periods of water stress. This potentially concerns watering of gardens for example, as well as the filling of swimming pools and a requirement to cover pools when not in use.

- Adjusting treatment processes in line with water quality requirements. This practice means that only water actually used for drinking purposes needs to be treated to potable standard. The water used in cement kilns and for the irrigation of parks and gardens is still treated, but to a lower standard. This makes it possible to reduce the amount of water treated to potable standard and to reduce drinking water demand in the process.

Figure 6 shows trends in per capita water demand over the past two decades. This demand includes non-domestic uses,

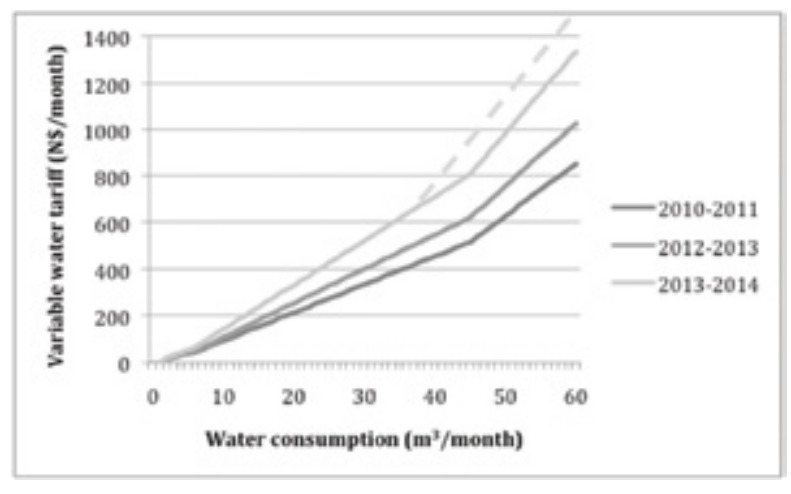

Figure 5: Evolution of the variable part of the water tariff in Windhoek as a function of water consumption per connection (between 2010 and 2014) (the dotted line is the low water availability tariff for 2013-2014).

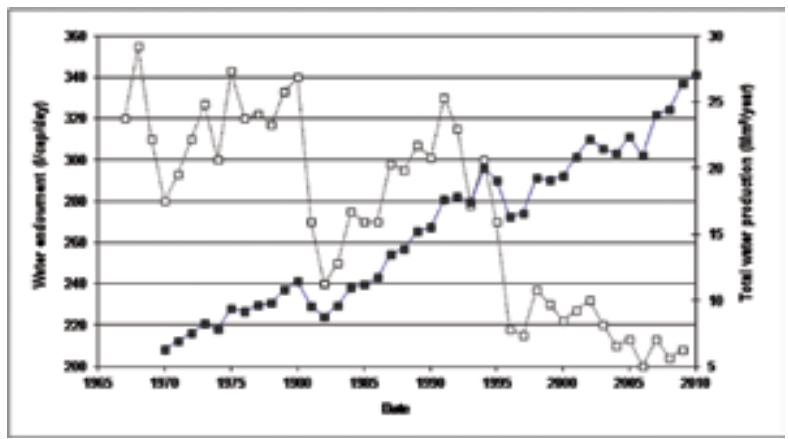

Figure 6: Evolution of the per capita water endowment in Windhoek (white boxes) against the evolution of water production (black boxes). which account for roughly $20 \%$ of total demand. The graph clearly illustrates the transitory but significant impact on per capita water endowment of two episodes of water stress that occurred in the eighties and mid-nineties respectively. These episodes prompted the municipality to restrict water usage, raise tariff thresholds and launch communication campaigns targeting consumers. These measures resulted in a $15 \%$ reduction in total demand and per capita demand reductions of between $25 \%$ to $30 \%$ (the difference between the two figures is attributable to population growth in the intervening period). It can also be seen that the first dip in demand did not last, with consumption returning to previous levels within six to eight years of restrictions and tariff pressures being eased. The second episode of water stress was better managed, since per capita demand has remained more or less stable ever since. These trends serve to demonstrate the impact that incentive measures and restrictions can have as well as the need to keep such measures in place to prevent a return to the status quo.

\section{THE LESSONS LEARNED AND THEIR ADAPTATION TO THE MEDITERRANEAN CONTEXT}

Desalination is a source of drinking water that offers the prospect of a long-term solution for the Mediterranean regions. The technology has still high energy requirements however, and is only feasible for coastal areas (so not in all contexts). It is therefore necessary to look at other nonconventional supply sources, the success of which will depend on a number of factors.

The first determinant is the institutional framework. Clearly there is a need for legislation allowing the rapid adjustment of water tariffs, as well as regulations allowing the reuse of water (whether stormwater, grey water or wastewater) for all or some domestic and industrial purposes. Moreover a full water cycle approach is critical when it comes to water management. In Windhoek, water supply and wastewater treatment are managed together which means that wastewater can be reused for different purposes including irrigation and drinking water production. Such strategies have also been adopted in Singapore where the management of the water cycle is centralised by a single body: the PUB.

The impediments to such practices are clear, including in the northern Mediterranean countries. In France, the use of treated wastewater in drinking water production is prohibited for sanitary reasons, but also no doubt because France has yet to experience water stress of a kind that threatens the supply of drinking water to cities. Wastewater is thus considered as a potential resource for parks, gardens and irrigation - in itself it is a first step towards protecting drinking water sources, though the leap to drinking water production has yet to be made. There is a strong likelihood however that western France (and in particular the south-west and the area between the Loire and Garonne rivers) will experience summertime water stress in the period between 2050 and 2070 and possibly even before then (as studied by the project Explore 2070). And, without the need to look so far ahead, parts of Spain like Catalonia and Andalusia are already severely affected by water stress - a problem that the country has sought to address by developing non-conventional technologies like desalination and wastewater reuse for irrigation. But here too, the line into drinking water production has still to be crossed. 
Wastewater reuse is only feasible with a proper understanding of the relevant technologies. The case of Windhoek shows that it is possible to acquire those skills even in a country of the southern hemisphere. It is indeed a success story that opens up prospects for developing countries too.

At this point, the question of the social acceptability of using treated wastewater must be posed. Whereas in most cities the use of wastewater for drinking water production comes up against problems of acceptability among the population (Po et al., 2003), the CoW has been reusing wastewater for over 40 years now with the approval of its citizens. The reason for this is most certainly the absence of any economically viable alternative. Practically, what is really amazing is that even the richest part of the city effectively use the water network for drinking water purpose, whereas for instance Indian rich people tend to add complementary treatment prior to use the water from the network. Moreover, bottled water is no more used than elsewhere. It means a deep citizens acceptance of the water reuse, and their trust in the capacity of CoW to treat this water.

Basically, the population acceptance of reusing water is a key aspect. As above mentioned, Windhoek informed its population of the new scheme when it was implemented forty years ago. But the city was already in a water stress context and no other option existed. What could be the issue in a city where other options exist? A part of the answer comes from Singapore (Lafforgue et al., 2015a). This city is currently supplied by 4 resources: water from Malaysia, rainwater, reused water (mainly named NEWater), and desalinated water (Table 2 provides the partition of water production from these resources). Singapore mainly reuses water for industrial needs (industries consume roughly half of the water production). A limited part of the reused water is injected in the reservoirs that store rainwater, and from which the water is treated for drinking water. This scheme includes a disconnection of the reused water from the drinking water by inserting a semi natural purification step (consisting of opened reservoirs). Moreover, the reused water is twice treated. Indeed, the NEWater includes a complete treatment that provides drinking water quality, and this water is again treated after being blended with rainwater. Singapore also organised a huge advertising campaign promoting the NEWater quality and providing that water in bottles (Tortajada et al. (2013). Extrapolating that to the specific context of Mediterranean cities, as several cities are located in a water stressed environment and have industrial activities (for instance it is the case at present in Catalonia, Murcia, Valencia, or in Alger, and in the future in the Nile Delta or in Istanbul) one option to study could be to supply these industries with reused water, when industrial activities are grouped in a dedicated place and then easily supplied. Dedicated studies are necessary to evaluate each potential case because it depends of a lot of contextual parameters. Regarding potential water reuse for drinking water, it totally depends of institutional, regulatory and social aspects. For instance it is strictly forbidden in France.

A potential drawback of wastewater reuse loops for drinking water production is the progressive increase in the salt content of the recirculated water. The parameters that this can affect will depend on the case. In Windhoek, the problem is one of general salinity levels and nitrate concentrations (Van der Merwe et al., 2006, Van der Merwe, 2009). This concern extends to groundwater as this too is now part of the city's wastewater reuse loop. Clogging of injection wells can compound the problem, so organic carbon concentrations must be monitored carefully and chlorine added to the water prior to injection to minimise the risk of bacterial regrowth in the filter medium. This problem should be expected wherever managed aquifer recharge is used. It is important to look at ways of minimising the risks associated with recharge and to keep close track of dissolved salt concentrations during the abstraction process.

Today's wastewater reuse systems tend to be of the semi-open loop type. This is indeed the case in Windhoek and Singapore (Lafforgue et al., 2015a) and is a factor that reduces the risk of a progressive rise in salinity levels. Table 2 illustrates that by comparing water resources in Windhoek and Singapore. In both cities water reuse roughly represent $1 / 4$ of the production in agreement with the semi-open loop principle.

In the likely event that the population of Windhoek continues to grow, the city will soon be faced with the need to increase wastewater reuse. The only way to address the dilemma posed by the shortfall in resources and deteriorating water quality is to keep dissolved salt concentrations down by using more efficient membrane filtration technologies like nanofiltration or reverse osmosis. Such technologies are currently used in Singapore, but in Windhoek filtration technologies are limited to ultrafiltration as provided as a final stage of treatment at the new Goreangab reclamation plant (figure 1). Once water needs exceed existing supply capacities, an additional nanofiltration or reverse osmosis treatment will no doubt be necessary.

Such technologies can be problematic in terms of cost, since they drive up energy requirements significantly as Lenouvel et al. (2014) have shown for Singapore. While this problem is not necessarily critical in countries with access to cheap fossil fuel reserves (as is presently the case in Algeria and Libya, for example), it may well become problematic in the Mediterranean countries in the future, many of which have limited fossil fuels or fossil reserves that are likely to be exhausted by 2050. These countries will have to count on technological breakthroughs (as did Singapore (Puah, 2011; Lenouvel et al., 2014)) to reduce the energy requirements of membrane filtration. Indeed the prospects are encouraging, the expectation being that it will be possible to halve the energy requirement (to around $2 \mathrm{KWh} / \mathrm{m}^{3}$ or even less) of reverse osmosis going forward.

Table 2: Partitioning of the water resources production in Windhoek and Singapore.

\begin{tabular}{|l|l|l|}
\hline & \multicolumn{1}{|c|}{ Singapore } & \multicolumn{1}{c|}{ Windhoek } \\
\hline \multirow{4}{*}{ Water resources } & Surface water from Malaisia : $40 \%$ & Underground water: $5 \%$ \\
\cline { 2 - 3 } & Rainwater : $30 \%$ & Surface water: $72 \%$ \\
\cline { 2 - 3 } & Seawater $: 8 \%$ & Seawater $: 0 \%$ \\
\cline { 2 - 3 } & NEWater (reused water): $18 \%$ & Reused water for drinking water: $18 \%$ \\
\cline { 2 - 3 } & Industrial reused water: $4 \%$ & Reused water for irrigation: $5 \%$ \\
\hline
\end{tabular}


Another important issue is the need to adjust treatment processes in accordance with the purpose for which the water is to be used (Lafforgue et al., 2013). This will be simpler if uses are centralised (with all industrial facilities being located at the same site for example), and if a separate reticulation system is dedicated to these uses. Windhoek has very little industry but what was formerly the drinking water distribution system is now partially used for the needs of parks and gardens and the cement plant. Singapore, with its reticulation systems for industrial facilities on Jurong Island (Lafforgue et al., 2015a), is a textbook case of this type of approach. By concentrating the facilities in the same place, it is possible to limit the linear footprint of these systems. They also have the advantage of optimising the fit between the treatment process used and the requisite quality of the treated water, which does not necessarily have to be potable. The result is that not all water is treated to potable standard, and in particular water used for purposes that do not warrant such levels of treatment.

Paris is another enlightening example. The city has a dual reticulation system, one of the components of which is the former drinking water system which was replaced in stages in the early part of the twentieth century. This system covers nearly all of Paris and is used for watering the city's parks and gardens as well as some industrial needs, street cleaning and sewer flushing. The system is supplied by water from the Seine River which undergoes only minimal treatment. This is another example of the "fit for purpose" principle, which does however require the different systems to be completely separate so as to prevent any connection errors.

Achieving a balance between supply and demand requires work on both sides of the equation. As in the case of both Windhoek (as described in this article) and Singapore (as described by Lafforgue et al., 2015a), the process of optimising demand is an ongoing one which is achieved by a raft of different measures including reducing water losses, educating consumers, effective and flexible tariff structures and suitable legislation (restrictions, use of water-saving devices, etc.). Indeed, making the use of water-saving devices compulsory can have a significant impact as Tortajada et al. (2013) have shown in the case of Singapore.

Combining all or some of the measures outlined above can reduce water demand considerably. The proportion of water abstracted from conventional supply sources is diminished when water supply system efficiency improvements are introduced, when there is a pro-active incentive policy and when non-conventional supply sources such as wastewater and rainwater are used. Indeed, in the case of Windhoek, the amount of water abstracted from conventional resources for domestic purposes is $125 \mathrm{l} /$ capita/day. And Singapore, a city with a hot climate and among the highest living standards in the world, has a domestic demand from conventional resources of only $75 \mathrm{l} / \mathrm{capita}$ /day. So there is clearly room for improvement when it comes to reducing the footprint of urban water demand - improvements that can be achieved with a genuine and sustained political will and with the appropriate institutional, regulatory, economic, sociological and technological mechanisms.

\section{CONCLUSION}

A lack of water resources in conjunction with growing water needs is a problem faced by many Mediterranean cities. Global warming will only exacerbate this problem going forward. Pioneering cities like Windhoek point the way to reducing pressures on resources. At $30 \%$ to $70 \%$, the potential gains to be achieved are considerable. To that end, the following conditions are necessary: a stable and sustainable urban policy framework; an institutional structure that allows different types of water (including wastewater and drinking water) to be managed together so as to benefit from the synergies to be derived within water cycles; the appropriate technical skills; and suitable legislation governing water usage and tariff structures among others. This approach is also feasible in cities with low-income populations, thereby opening up prospects for countries in both the Mediterranean basin and beyond.

\section{ACKNOWLEDGEMENTS}

Our special thanks go to the people of the CoW and Namwater in Windhoek for their constructive input and help. We would also like to thank the partners in the SYRACUSE project (LATTS, Science Po, CIRSEE, EXPLICIT, the Plaine de France Development Corporation, and Suez Consulting (former SAFEGE company)), and in particular Morgan Mouton for his insights on political, social and organisational issues in Windhoek.

\section{REFERENCES}

2030 Water Resources Group (2009) - Charting our water future. Economic frameworks to inform decision making. $198 \mathrm{p}$.

Lafforgue M., Lenouvel V., Chevauche C. (2013) - The Syracuse Project: a global approach to the management of water uses in a urban ecosystem. In GWF-Wasser-Abwasser. 154-S1 72-78

Lafforgue M., Lenouvel V., Chevauche C. (2014) - Les systèmes décentralisés et la durabilité des cycles de l'eau en ville. Technique Science et Méthode. 11 73-82

Lafforgue M., Lenouvel V. (2015a) - Comment Singapour et Windhoek adaptent les cycles urbains de l'eau pour surmonter leur dépendance hydrique. Technique Science et Méthode. 5 66-85

LAfForgue M., Lenouvel V. (2015b) - Closing the urban water loop: Lessons from Singapore and Windhoek cities. Submitted to Environmental Science: Water Research and Technology. $1622-631$

Lenouvel V., Lafforgue M., Chevauche C., Rhetore P. (2014) - The energy cost of water independence: the case of Singapore.Water Science and Technology 70 (7), 787-794

Lahnsteiner J., Du Pisani P., Menge J., Esterhuizen J. (2013) - More than 40 years of direct potable reuse experience in Windhoek. In Milestones in water reuse, the best success stories, Lazarova V., Asano T., Bahri A., Anderson J. (Eds). IWA publishing. 351-364

Matthews S. (2003) — The Water Wheel: Artificial recharge schemes - A novel method to "bank" water. Lecture prepared by DWAF for students of integrated cater resource management, hydrology, hydrogeology and water supply engineering.

Murray R., Van Der Merwe B., Louw D., Menge J. (2013) — The Windhoek Managed Aquifer Recharge Scheme: Conception, implementation, operation and expansion. 9th IWA water reuse conference Windhoek, 27-31 october 2013.

Peters I. (2013) - Windhoelk managed aquifer recharge. 9th IWA water reuse conference Windhoek, 27-31 october 2013.

Plappally A.K., LIENHARD V J.H. (2012) - Energy requirements for water production, treatment, end use, reclamation, and disposal. Renewable and Sustainable Energy Reviews. 16 4818-4848 
Po M., Kaercher J.D., NAncarrow B.E. (2003) - Literature review of factors influencing public perceptions of water reuse. CSIRO Land and Water Technical Report. 54

PuAH A. K. (2011) - Smart water - Singapore case study, smart water cluster workshop. IWA-ASPIRE conference, Tokyo, 2 October 2011.

RygaArd M., Binning P.J., Albrechtsen H.J. (2011) — Increasing urban water self-sufficiency: New era, new challenges. Journal of Environmental Management. 92 185-194

Tortajada C., Joshi Y., Biswas A.K. (2013) - The Singapore water story. Sustainable development in an urban city state. Routledge, Taylor and Francis group. 286 p.

VAN Der Merwe B. (1999) — Implementation of integrated water resource management in Windhoek, Namibia. Proceedings of the 4th Conference of the IAHR, Namibia. $9 \mathrm{p}$.
Van Der Merwe B.; HaArhoff J.; Menge J. (2006) — Wastewater treatment and reuse: a potential source for potable water supply augmentation. Proceedings of the National Water Forum/ Conference on Water Resources Management, Gaborone, Botswana, 24 -25 July 2006. 17 p.

VAn Der Merwe B. (2009) - Closing the urban water cycle integrated approach towards water reuse in Windhoek, Namibia. In Urban Water security: managing risks, edited by Blanca Jimenez and Joan Rose, Urban water series -UNESCO-IHP, Taylor and Francis. 221-236

Van Der Merwe B., Drews H., Peters I. (2013) - Securing water supply to Windhoek through unconventional resources. 9th IWA water reuse conference Windhoek, 27-31 october 2013. 